\title{
Teaching Politics Abroad: The Internationalization of a Profession?*
}

\author{
Thomas W. Smith, Koç University
}

The dismal state of the American academic job market is a favorite topic of commiseration among political scientists looking for work. In this case, misery has plenty of company. In one recent year, only $37 \%$ of political science doctoral students landed continuing appointments, not to mention the many professors who each year seek more rewarding positions (Yin 1998). Even the comic strip "Doonesbury" has lampooned the peregrinations of academic "gypsy workers," desperate for adjunct or short-term posts.

Job prospects overseas look markedly brighter, although competition is also stiff for choice appointments. One observer calls international higher education "one of the world's most rapidly expanding lines of business" (Tysome 1999, 8). Another notes that international education is emerging as "one of the brightest and most productive ways of bridging the "culture gap"' (Anderson 1999, 19). Better higher education worldwide, new private universities, a sharp rise in English-language instruction, and a revolution in student demographics all herald a robust international academic market for at least the next generation. Burgeoning demand may lure many American political scientists to overseas posts, in turn prompting new dilemmas over academic freedom

Thomas W. Smith is assistant professor of international relations at Koc University in Istanbul. He has published articles in History of Political Thought and Ethics \& International Affairs, and is the author of History and International Relations (Routledge, 1999). He completed this essay while he was a visiting scholar at the Center for Middle Eastern Studies at Harvard University. His email address is Tsmith@ku.edu.tr. and the "Americanization" of international education.

\section{The Changing Face of International Higher Education}

While net enrollments in U.S. colleges and universities have risen only slightly over the past 15 years, they have climbed dramatically elsewhere, and continue to soar. The number of university students worldwide is forecast to grow from 48 million in 1990 (about 14 million of them in the United States), to 97 million in 2010, and to 159 million by 2025 (Blight 1995).

Much of the new demand for university instruction will no doubt be met by expanding distance education programs and developing other new modes of teaching. Still, exploding enrollments overseas-and a steep relative decline in the number of North American students-mean that international demand for professors will almost certainly outstrip U.S. demand. According to a 1999 British government report, there is already in the developing world "an insatiable demand for high-quality, cost-effectively delivered, tertiary education in English" (Tysome 1999, 8). Simply to maintain enrollment rates at current levels in developing countries, one sizeable new university has to open every week (Daniel 1996).

In recent decades, "international-

\section{TABLE 1}

Projected University Enrollments, 2025 (Thousands of Students)

\begin{tabular}{lrrr}
\hline & $\begin{array}{c}\text { Population } \\
\text { 18-21 Years Old }\end{array}$ & $\begin{array}{c}\text { All } \\
\text { University Students }\end{array}$ & $\begin{array}{c}\text { Percent Participating in } \\
\text { Higher Education }\end{array}$ \\
\hline Africa & 131,221 & 15,427 & 11.8 \\
America & 68,273 & 34,508 & 50.5 \\
North & 17,767 & 11,377 & 64.0 \\
Central & 18,295 & 8,429 & 46.1 \\
South & 32,211 & 14,703 & 45.6 \\
Asia & 265,793 & 86,520 & 32.6 \\
North East & 86,853 & 33,248 & 38.3 \\
South East & 42,122 & 14,425 & 34.2 \\
South & 110,873 & 31,393 & 28.3 \\
West & 25,946 & 7,454 & 28.7 \\
Europe & 48,969 & 21,847 & 44.6 \\
West & 20,392 & 10,537 & 51.7 \\
East & 28,577 & 11,309 & 39.6 \\
Oceania & 1,973 & 982 & 49.7 \\
World & 516,231 & 159,283 & 30.9 \\
\hline
\end{tabular}

Source: Blight (1995)

Note: The National Center for Educational Statistics (1997) projects somewhat stronger growth in the U.S. market through 2007, due to the increased rate of enrollment for older, "nontraditional" students. The NCES figures still point to a coming decline in the number of students in North America relative to other parts of the world. 
ization" in higher education has referred to the large numbers of foreign students studying in North America and other "core" regions. According to the Institute of International Education, 481,000 foreign students matriculated at U.S. schools during the 1997-98 academic year; other popular destinations for foreign students were Britain (196,000), France $(130,000)$, and Australia $(93,000)$. American dominance in teaching foreign students may be waning, however. In the past 10 years, the U.S. share of the foreign student market has fallen from 40 to $30 \%$. As a percentage of all students, the number of those studying overseas is also declining. Not only do students find it cheaper to study in their home countries (most foreign students in the U.S. pay full tuition), but new development strategies are prompting many countries to train their own elites and develop their own expertise, even if that means recruiting foreign faculty.

Geopolitical shifts also can loosen-or tighten-ideological reins on appointments. Academic exchanges were certainly instruments of Cold War policy, albeit far down the order of battle, and may yet be manipulated by members of regional trade blocs. As strategic concerns recede, governments may be less inclined to invest in overseas education.

Equally, in an age of economic liberalism, state-sponsored placements may give way to market-driven ones. In the case of the U.S. Fulbright program, the invisible hand has yet to displace state support. Expected dividends in the form of democratic development and open markets have sustained Washington policymakers' bipartisan interest in the program, although, in real terms, Fulbright funds have been steadily trimmed over the past decade.

The adoption of "world languages," notably English, for university instruction around the globe is further propelling the internationalization of higher education. For better or worse, a command of English is nearly required for membership in the international scholarly community. Most of the world's 100,000 academic journals are published in English, and English dominates in-

\section{Is Your Course Syllabus Online?}

APSA is working to build a database of online syllabi as part of the "Teaching Political Scinece" component of APSANet. We'd like to include your materials. Be sure to visit www.apsanet.org/teach/ and provide the URL to your syllabus.

\section{APSANet, It's a Resource. Check it Out}

ternational conferences, research monographs, Internet sites, listservs, newsletters, and databases (Altbach 1998, 48). For students preparing to make their way in a shrinking world, incentives to master English are at least as great. English has long been the lingua franca at European business schools, such as Insead and Bocconi, and at research centers, such as the College of Europe at Bruges and the European University Institute outside Florence. Increasingly, English is the medium of instruction in an array of degree programs, especially those with an international flavor such as international relations, international law, European studies, and political economy.

Finally, the sun may be setting on the classical idea of the university. Results of a recent survey suggest that the international university is increasingly "an incubator of new industries in a technology-dominated economy," devoted less to reflecting on moral issues or transmitting cultural values and more to the efficient flow of technical knowledge (The Economist 1997, 5). Such universities may encourage faculty mobility, but may also foster the development of bland, deracinated curricula.

\section{The Peripatetic Professor}

Despite rhetorical zeal for internationalization, most professors remain acutely nation-bound. A survey of 20,000 academics in 14 countries conducted by the Carnegie Foundation for the Advancement of Teaching found that only one-half of $1 \%$ of teaching-oriented faculty had ever held an appointment in another country; slightly more than $1 \%$ of research-oriented faculty had held a foreign post. ${ }^{1}$

Reliable figures are scarce, but the number of itinerant scholars appears to be growing. Philip Altbach, director of the Center for International Higher Education at Boston College, recently estimated there are 100,000 or more faculty currently holding positions outside their home countries, about half of whom work in the U.S. The most visible of these are sponsored by states and state consortia: the U.S. Fulbright program, the British Council, the German Academic Exchange Service, the Japan International Cooperation Agency, and various EU exchanges. Currently, about 700 American scholars and professionals, $10 \%$ of them in political science and related fields, serve as Fulbrighters each year. In Europe, the ERASMUS and SOCRATES programs have arranged some 15,000 intra-EU faculty swaps since 1987 , and new EU networks extend to Eastern Europe, the Mediterranean, and the Americas.

Most foreign academic appointments, however, are made independent of formal exchange and placement programs (Allaway 1991).

Anthony Welch (1997, 325-26) called attention to this phenomenon of the "peripatetic professor," a reference to Aristotle's habit of "walking about" the Lyceum while discoursing on life's great questions. The practice was carried forth by the Sophists, who took their moral and rhetorical teachings on the road for pay; by Arab scholars, who migrated to Europe in the twelfth and thirteenth centuries and brought the Greek classics with them; by professors in the High Middle Ages making the peregrinatio academica 
among the grand European universities-Bologna, Leyden, Padua, Paris, Prague-while offering a standard curriculum taught in Latin; and the European scholars who fled in the 1930 s to the U.S., Britain, and other academic havens.

Today's peripatetic faculty are predominantly economic immigrants. The peripatetic movement mirrors a liberalizing trend in professional services in general, and growing fluidity in academic appointments in particular (Kameoka 1996). A number of foreign schools devise their own overseas teaching programs and exchanges or directly recruit foreign staff. Following in the footsteps of the English Speaking Union and the Rhodes Scholarship Socjety, a new generation of NGOs is also placing faculty in overseas posts. The Civic Education Project, for example, each year funds about 200 visiting lectureships in 19 countries across Central and Eastern Europe and Central Asia.

On the supply side, some freelance faculty follow their research interests or take advantage of foreign contacts, while others look overseas out of a sense of service or a commitment to international development. But most peripatetics simply take a global view of the job market and seek regular, continuing -if not always tenurable-appointments abroad. Barriers to entry can be high, but are not insurmountable, particularly if one teaches at an English-language institution. In contrast to strict licensing requirements for primary and secondary school teachers, a doctorate is usually the only requisite for college or university professors, and states are relatively lenient in furnishing academics with residence and work permits. $^{2}$ Some governments mandate national preference in faculty hiring, but the Carnegie Council survey found that, overall, overseas institutions were more committed than American schools were to hiring foreign staff.

\section{Rewards of Teaching Politics Abroad}

Peripatetic faculty report frustrations with language, incomprehensible pay stubs, snail-paced Internet connections, bureaucratic nightmares, and so on, although conditions vary widely. There are no universal standards for tenure, academic freedom, and curriculum, and, to a degree, peripatetic professors feel the insecurities experienced by guest workers everywhere. One Fulbrighter part jokingly described himself as a "halfbrighter" for having gone in the first place (quoted in Welch 1997, 337).

Many faculty use overseas appointments to develop new research, to hone their teaching skills, or to broaden their personal and professional horizons. Peripatetic types also cite the siren call of exotic lands or the thrill of living in a world city as "pull" factors. For students of politics, teaching abroad is an intellectual boon before all else. Dilemmas that seem uncomplicated from afar take on color and complexity when viewed from ground level; the raw edges of politics are exposed to researchers in country in a way they never are to distant observers. An overseas post can unlock a treasure-house of research possibilities. In Turkey, where I teach, newspaper headlines read like the syllabus for a survey of international politics: Islamic activism, ethnic strife, terrorism, human rights abuses, regional geopolitics, the political economy of oil, and economic and political integration. Foreign observers may be handicapped by poor language skills and a shortage of "cultural capital." On the other hand, like de Tocqueville, they may gain insights that are hidden from people steeped in the local culture.

Events can also enliven musty political theory. Turkey's Kemalist state-building brings to mind Bodin (and Machiavelli). For confirmation of Marx's prophecies about the effects of capitalism on traditional so- cieties, one has only to look out the window at the urban upheavals of Istanbul. In this city on the Bosphorous, the tankers and freighters that ply the strait strip the abstraction from discussions of international trade. One may also face the boundaries of Western political ideas. For example, a recent Turkish law bars veiled women students from the country's universities. From a liberal perspective, one respects expressions of faith or modesty; equally, one is wary of a religious movement that, at times, seems intent on toppling the secular order and imposing Islamic law. As much as one tries to

\section{Finding a Job Overseas}

Fulbright exchanges are administered by the Institute of International Education ( $w w w$.iie.org) and the Council for International Exchange of Scholars (www.cies.org). The Council on International Educational Exchange ( wmw. ciee.org) offers faculty development seminars and international placements. The web site for the Civic Education Project is (wmw.cep.org.hu).

The American Political Science Association and the European Consortium for Political Research recently launched the APSA/ECPR Scholar Clearinghouse to facilitate exchanges between U.S. institutions and those in ECPR member countries (www. apsanet.org/exchange).

Regular appointments overseas are occasionally advertised in APSA's Personnel Services Newsletter, the North American newsletter of the International Studies Association, and the British ISA newsletter. International positions are also posted in The Economist and the Times Educational Supplement (www.jobs.tes.co.uk). The Chronicle of Higher Education (hHtp://chronicle.com/jobs) will sort non-U.S. job listings. International Exchange Locator (Institute of International Education, 1998) and Pamela George's College Teaching Abroad: A Handbook of Strategies for Successful Cross-Cultural Exchange (Allyn and Bacon, 1994) are helpful.

Excellent general resources include the Boston College Center for International Higher Education (wuw. bc.edu/cihel, the UNESCO-affiliated International Association of Universities (wuw.unesco.org/iau), and the Alliance for International Educational and Cultural Exchange (www. alliance-exchange.org). 


\section{A Sketch of the International Professorate}

The findings of the Carnegie Council survey shatter the stereotype of international teaching as a haven for eccentric expatriates. The survey, which included foreign professors working in the U.S., found that peripatetic teachers belong to the more dynamic and research-oriented arm of the profession (Lewis and Altbach 1995; Welch 1997)

- Foreign teachers were more motivated to do research then their "indigenous" colleagues were. Peripatetic faculty published more, attended more conferences, and tapped into broader professional networks than local faculty did. Internationalization appeared to foster research, and vice versa.

- Women academics were underrepresented among foreign faculty. However, women who did teach abroad were more likely than indigenous faculty to be of higher academic rank. Three-fourths of the professors polled were men.

- Professors in all 14 countries enjoyed roughly the same level of job satisfaction, although foreign staff were more likely than local staff to intend to leave their posts. Faculty declared stronger loyalty to their disciplines and departments than to the institutions they served.

- Foreign faculty were more likely than their indigenous colleagues to be employed full time and to hold senior appointments.

- Higher education faced fiscal strains in almost all the countries under study, and $60 \%$ of respondents believed that respect for academics was declining in their countries. Nevertheless, faculty were remarkably optimistic about teaching, research, and their professional obligations to society. Fewer than $20 \%$ of those polled regretted their career choice.

- Professors generally felt that their academic freedom was safeguarded, although responses ranged from $92 \%$ in Israel to $16 \%$ in Russia. Eighty-one percent of U.S. faculty considered their academic independence "strongly protected." When professors were asked if their own university administrators supported academic freedom, agreement plummeted, to a startling low of $18 \%$ in Germany. distinguish between personal and political acts, in many cultures the two are inseparable.

Insights into political culture are perhaps the richest reward of teaching overseas. One sees firsthand the gap between democratic institutions and democratic practices, the pillars of national identity, the seamless web of domestic and foreign policy, and so on. In Turkey, the effects of a top-down culture are pervasive. Intense nationalism coexists with acid cynicism toward the country's politicians, who often behave more like profiteers than public servants. Barbs directed at the U.S. and Europe are the stock and trade of many students, yet the same students hesitate to challenge Turkish policies. Critical thinking is not encouraged in lower schools, and student essays occasionally lapse into rote paeans to Atatürk or mythical recitations of Turkish history. Politics, as a discipline, is grouped among the "administrative sciences," a tradition rooted in the training of imperial mandarins, now grafted onto the modern idea that society can be molded like wet clay.

\section{New Opportunities}

New "American" universities (institutions accredited or seeking accreditation by U.S. college and university associations, several of which receive money from the U.S. Congress) are springing up in unlikely places like Azerbaijan, Kazahkstan, and Sharjah, a Lilliputian emirate on the Persian Gulf. Others are planned for China and South Africa. These join established American universities in Bulgaria, Cairo, London, and Paris. The American University of Beirut, which opened its doors in 1866 and has long been the flagship of American schools overseas, is undergoing a major revival. Overseas satellite campuses of American universities are proliferating as well. The "franchise" model was developed by British and Australian universities and pursued in earnest in the 1980s. Many U.S. institutions (not without cries that university overseers are selling a school's good name) are now following suit. Franchise packages typically provide for student and faculty exchanges between branch campuses and the home school.

More importantly, the structure of many states and economies vis-à-vis higher education is changing. In countries with stagnant state revenues and caps on public admissions, many new schools are in the private sector. These are often small, innovative institutions that embody a "civil society" approach to higher education and whose existence may be perceived as a challenge to lumbering state universities, which in many countries have monopolized higher learning. Foreign job seekers may find private schools more accessible than public ones, where civil service laws frequently require staff to be national citizens.

Singapore, Hong Kong, Malaysia, Thailand, and Taiwan all have impressive academic infrastructures and anticipate vast growth. Singapore is intent on becoming a regional "center of excellence" by persuading world-class universities to open branches there. So far, Insead, MIT, Chicago, Carnegie-Mellon, Georgia Tech, and Johns Hopkins have signed on with programs that focus on technical and professional education rather than the liberal arts. Changes in Hong Kong, historically a magnet for foreign faculty, are also of interest. The former British colony plans to rapidly double the number of students at its seven universities. It, too, has developed joint ventures with overseas schools, emphasizing English-language graduate and research programs. As part of the hand-over to China, however, a number of prominent PRC faculty were stationed to Hong Kong universities, and administrative appointments tilted in Beijing's favor. For now, Hong Kong carries on its version of liberal learning and can still boast the most internationally diverse (and probably the best paid) faculty in the world. Nine-tenths of Hong Kong professors received their Ph.D.s overseas, and $40 \%$ are themselves foreign.

In Germany, a cumbersome tradition of appointing faculty has slowed internationalization. However, several programs are being revamped in hopes of attracting more interna- 
tional students and faculty. A number of private universities, in which much of the instruction will be in English, are also planned to fill the gap between traditional universities and the Fachhochschulen, or vocational schools. Unfortunately, education officials in Germany and several other European countries continue to resist accrediting foreign-model colleges and universities, further hindering internationalization (Anderson 1999). In Britain, newly implemented competitive research rankings and a desire to offset the "brain drain" of prominent British faculty have universities scrambling to hire international scholars with strong research vitae. Turkey has long welcomed foreign faculty. Scores of academics fleeing Germany during the 1930s boosted Atatürk's westernizing education reforms. More recently, changes to Turkish legal and tax codes have allowed for the establishment of "foundation universities" (vakif üniversitesi). More than 25 of these schools, some of them excellent, have been founded since 1992. Most use English as the medium of instruction and employ significant numbers of foreign staff. Political science and/or international relations are standard programs.

In Eastern Europe, private universities represent the fastest-growing sector of higher education and, in several countries, now account for a quarter or more of tertiary enrollments. Conditions remain bleak for political science professors in Russia (Shestopal 1999). Prospects are perhaps marginally brighter in the country's 200 or so new private institutions, although corruption is commonplace and some schools are little more than diploma factories (MacWilliams 1999). Russia has also seen the advent of "nonstate" universities, such as the European University at St. Petersburg founded in 1994 by the city of St. Petersburg. The school, which specializes in Russian studies, has already hired several prominent international scholars. In Poland, Hungary, Romania, and Azerbaijan, dozens of new private universities have recently been accredited, and there are hundreds more of erratic quality.
Several institutions strong in social science, such as Central European University in Budapest and the Moscow School of Social and Economic Sciences, have quickly gained international reputations (Bollag 1999). CEU is doubly important because its faculty outreach and curriculum development projects have helped to "seed" other institutions in the region.

Significant reforms are clearly afoot. But this is not to say that a golden age of international higher education lies on the horizon. Colleges and universities are besieged almost everywhere. Around the globe, administrators have cast tenure into doubt, faculty face increased pressure to publish, and resources have been slashed. In the short term, new institutions may have mixed appeal for foreign staff. The case of CEU is instructive: since the school was founded in 1991 , virtually the entire original American staff has departed, most for financial reasons. In the roughand-tumble global higher education market, shady for-profit institutions have emerged, as has the practice of "twinning" local schools with offshore degree mills. Foreign governments have responded by tightening accreditation criteria. Also, according to the American Council on Education, 95 overseas schools have been accredited by college and university associations in the U.S., often after upgrading faculty, curricula, and libraries to meet American standards.

\section{Academic Freedom}

Academic freedom is generally strong around the world, and has proved remarkably resilient in some circumstances. In Latin America, for example, there are cases where traditional academic freedoms have prevailed even when formal constitutional protections were in disarray. Nevertheless, political taboos still hold sway on many campuses. The Human Rights Watch Academic Freedom Committee has identified several dozen countries where academics have been targeted for criticizing public policies, participating in opposition political parties or

\begin{tabular}{|c|c|c|}
\hline & Yes & No \\
\hline Australia & 77 & 23 \\
\hline Brazil & 38 & 62 \\
\hline Chile & 71 & 29 \\
\hline Hong Kong & 71 & 30 \\
\hline Israel & 92 & 8 \\
\hline Japan & 79 & 21 \\
\hline Korea & 74 & 26 \\
\hline Mexico & 69 & 31 \\
\hline The Netherlands & 74 & 26 \\
\hline Russia & 16 & 84 \\
\hline Sweden & 83 & 17 \\
\hline United States & 81 & 19 \\
\hline
\end{tabular}

grassroots movements, or investigating politically sensitive topics.

As higher education becomes more international, clashes over academic freedom are likely to increase, particularly in relatively authoritarian countries and/or conservative societies. Universities in oil-rich states in the Middle East, for example, have made numerous peripatetic hires, yet many foreign faculty find conditions there oppressive. Ensuring academic integrity at branch campuses may prove particularly difficult. The University of Virginia recently abandoned plans to open a branch in Doha, Qatar. Although Qatar is one of the most reformist of the Arab Emirates, it nevertheless has a spotty record on guaranteeing human rights for women and members of religious minorities. Some UVA students and faculty feared the franchise would benefit from its association with "Mr. Jefferson's university" without observing Jeffersonian principles of tolerance and free debate.

In many countries, universities remain instruments of state building and ideological conformity. In Turkey, the State Higher Education Council was established following the 1980 military coup d'état. Corporatist in character, the council aims to guide higher education (public and private) in Turkey and, at the same time, to "depoliticize" cam- 
TABLE 3

In this Country, There Are No Political or Ideological Restrictions on What a Scholar May Publish (\%)

\begin{tabular}{lccc}
\hline & Agree & Neutral & Disagree \\
\hline Australia & 59 & 21 & 20 \\
Brazil & 46 & 24 & 31 \\
Chile & 75 & 16 & 9 \\
Hong Kong & 74 & 11 & 15 \\
Israel & 66 & 15 & 19 \\
Japan & 79 & 5 & 15 \\
Korea & 55 & 26 & 19 \\
Mexico & 35 & 22 & 43 \\
The Netherlands & 58 & 16 & 27 \\
Russia & 40 & 39 & 21 \\
Sweden & 78 & 11 & 12 \\
United Kingdom & 55 & 20 & 25 \\
United States & 49 & 17 & 34 \\
\hline
\end{tabular}

Source: Boyer, Altbach, and Whitelaw (1994) ness and media, and dutifulsometimes Pravda-like-journalism make informed discussion difficult. Even library books relating to volatile topics may not be ordered as requested.

There are subtler forms of coercion as well. Economists, for example, might discover it was politically imprudent to model a new way of tracking the country's inflation. For po-

puses of left-wing and religious activity. Following the coup, hundreds of professors thought to be politically unsound were relieved of their positions, and many others resigned in protest or stepped down rather than be reassigned to provincial universities (Szyliowicz 1994). During the politically tumultuous 1970 s and early 1980 s, the government rapidly expanded the number of state-sanctioned religious secondary schools, the Iman-Hatip lycées, perhaps on the theory that it was better to be a Muslim than to be a communist. Today, ironically, the state uses stern measures to muzzle Islamic activists at universities.

Although rarely invoked, provisions of the Turkish Law on Higher Education also cast a pall on free expression. Making "degrading” remarks about the Turkish state while abroad, for instance, is grounds for dismissal from a university professorship. Some calls for a political settlement to the Kurdish question have also been judged seditious, and offending Turkish professors have been imprisoned (as have journalists, human rights activists, a cartoonist, and a playwright). Most issues are freely discussed in the classroom, although I find it challenging to move students beyond the narrow range of media and official pronouncements. Unfortunately, censorship, collusion between busi- litical scientists, studying political violence as a general phenomenon is preferable to investigating ethnic strife or human rights violations in Turkey. Indeed, there seems to be a general preference for empirical work over normative studies, which might entail criticisms of or counsel for the prince. As in many countries, "political correctness" in Turkey means heeding received versions of history. One of my American colleagues, a psychologist, sparked a small scandal when he published a letter affirming that the Armenian genocide had, in fact, taken place and criticizing Turkish government efforts to manipulate scholarship on this issue. A troubling dilemma of academic freedom is that raising flags of controversy can draw fire against an entire institution. After my department sponsored a lecture on the genocide by an ArmenianAmerican historian, a Turkish Islamist magazine accused the University of indulging "enemies of Turkey."

Liberal institutions in illiberal settings can face terrible dilemmas. Professors at the American University in Cairo, for example, constantly balance their commitment to liberal doctrine and pedagogy against state and societal pressures. The school's U.S. accreditation and congressional subsidies do not shield it from Egyptian law. Every book AUC orders from abroad must pass government censors, who forbid items they consider pornographic or blasphemous. Societal pressures are equally acute. Cairo's Islamist media regularly denounce AUC as a hotbed of liberal and libertine mores. The school does not want to offend, and indeed recognizes that it is an American institution operating in Egypt. Unavoidably, this affects academics. In one recent case, a professor of modern Arabic literature was censured for assigning Moroccan writer $\mathrm{Mu}$ hammad Choukri's fictional autobiography, Streetwise (1996), which contains sexually explicit passages. Several students apparently found the material offensive and, at the behest of the students' families, university administrators pressed the professor-an Arab woman-to withdraw the text from her course. The university removed Choukri's book, along with several other "indecent" novels (all written by modern Arab or Muslim authors), from the school's collections.

Such compromises of academic freedom are probably inevitable in closed societies, and may even help to preserve the core mission of liberal institutions through cycles of intolerance. Other universities, some in highly developed countries, try to bend research and teaching to fit a specific political agenda. In both cases, decisions to curb academic expression are often arbitrary. Faculty may steer clear of issues they think will offend native sensibilities or state censors, be cowed into pursuing noncontroversial research, or abandon social criticism altogether.

\section{"Shopping Malls of the Mind?"}

Critics claim that teaching overseas, as either an official emissary or on one's own, has the odor of imperialism. They also lament that peripatetic faculty at elite schools are helping to create a global "management class" that deepens social and economic inequalities everywhere. In a subtler vein, Fred Halliday (1999, $99,101)$ recently attacked the "modish homogeneities" that pass for internationalization and urged faculty to resist curricula that resemble "an- 
odyne hotels or shopping malls of the mind."

Of course, "internationalize" often means "Americanize." Historically, foreign students earned Ph.D.s in the U.S., then carried the good word back to their countries. Today, international education is literally turning American. The U.S. is the single largest exporter of academic labor, as well as of teaching methods, intellectual fashions, and journals and textbooks, which frequently assume an American audience. U.S. teachers and teaching methods and materials probably do advance American political culture, norms, and even policy at the expense of local ways. Then again, there is much that is laudable about the "subversive" values that American education inculcates overseas (The Economist 1998).

Official American academic exchanges, first launched in response to Nazi Germany's "cultural offensive" in Latin America during the 1930s, have drawn criticism as well (Mulcahy 1999). Fulbrighters, certainly, have always been tools of American foreign policy, but only in the most general way. ${ }^{3}$ In the main, the program is nonpolitical or "cultural." Its sponsor and administrators believe that the best way to showcase U.S. values is to let American professors ply their trade without interference. It is considered poor form to use Fulbrighters as cover for intelligence operations, although embassies and other government bureaus do recommend specific placements. In the early stages of the Iranian Revolution, for example, the U.S. Embassy in Tehran proposed an exchange of American and Iranian theologians to help cut through "the great deal of confusion" surrounding Shi'a politics in the country (Graves 1979).

While the Fulbright program painstakingly avoids political entanglements, its aim is exactly to cultivate liberal ideas overseas. In the past, Fulbright awards explicitly discouraged grantees from making public political remarks and participating in political activities during their tenures in the program. In at least one case, senior U.S. officials voiced sharp displeasure at the political activity (attending a protest rally at the American embassy in Zimba- bwe) of a political science Fulbrighter after she had completed her official stint (Knight 1987). This lopsided "depoliticization" of the program has subsided in recent years. United States law now accords full academic and artistic freedom to all Fulbrighters. Notwithstanding, host countries may still veto any Fulbright candidate whose teaching or research is viewed as politically or otherwise controversial. Some host countries still prefer technical trainers to humanists (who might touch on such heresies as democracy or human rights), but today, Fulbright posts from Armenia to Zambia are extremely diverse, with fewer "prescribed" appointments and more "open" ones.

Nor are foreign schools mere pawns in internationalization. Many "globalized" universities have nationalist agendas (this generally being the reason they globalized in the first place), or, like some American research centers, are in league with national security machines. Nonetheless, globalization may elicit a domestic backlash. Elite, foreign-language universities often go to great lengths to demonstrate their patriotic bona fides, lest they be branded as too internationalist. Subtler forms of cultural definition and cultural resistance are also at work. WingWah Law (1996) modeled what he calls the "fortress state," which welcomes foreign knowledge for purposes of economic modernization, but erects barriers to the importation of social and political knowledge. Similarly, overseas institutions may embrace the American model, even as they mold it to suit local realities.

Rather than instilling a Goliath ideology, this sort of inverted colonialism produces a hybrid of Western and indigenous ideas. I teach international relations and political theory to Turkish students. I generally assign readings from the Western canon, although I occasionally draw on Islamic scholarship as well as texts from other intellectual traditions. To introduce the concept of just war, for example, I direct students to classical commentaries by Sunni jurists. Most of my students seem genuinely interested in the European tradition and even consider themselves part of that heritage.
Yet, they are also versed in Islamic thought, Central Asian and Ottoman history, Turkish republican doctrine, and the contemporary intellectual scene in Istanbul. Higher education that is Western in style and content does have the potential to detach students from their own traditions. A more likely result will be that students grow fluent in both academic cultures or synthesize the two.

This is not to deny that there are culturally distinct ways of understanding politics. Even "value-free" empirical work is freighted with Enlightenment assumptions about the unity and progress of science. One critic argued that the notion of an academic Internationale all-devoted to universal values is "perhaps an echo of an imperialist past that is better forgotten" (Scott 1998, 113). Basic human rights are nonnegotiable, but liberalism has its limits. Not everywhere are the designs of Smith and Mill obvious or preferable to more solidaristic forms of civil association. "Imparting citizen skills" and "teaching democracy" are catchy slogans, but political culture is not something that one carries in a suitcase to dispense upon arrival. The critical classroom, where diverse ideas are respectfully debated, can be a seedbed of democracy. At the same time, one may feel pangs of inauthenticity when teaching "liberal" politics in a society where there is real repression and fear.

\section{Fears of Professional Isolation}

One result of academic "colonialism" is that overseas faculty are in little danger of napping through the latest developments in American political science. Email, the Internet, and other advances in communications make it nearly impossible for peripatetic scholars to miss any news. Still, being overseas makes a difference. Interjecting ideas into the American debate from abroad, for example, often proves difficult. Some of my colleagues feel that journal editors in the U.S. may look askance at manuscripts received from an obscure foreign university. Conference proposals may be similarly received, perhaps out of concern that the panelist, once chosen, will not cross 10 
time zones to show up. When peripatetic faculty attempt to reenter the U.S. job market, search committees may wonder: "If she's so good, why is she in Ecuador?" Committees may worry that a professor has fallen out of touch with American students, or may balk at flying in an interviewee from overseas. It is probably true that the longer one teaches abroad the harder it will be to reenter the U.S. market. A study by the Council for International Exchange of Scholars found that faculty who spent time overseas lost graduate students, office space (!), and their position in the department pecking order. Also, promotion and tenure boards often regarded time spent overseas as "fun and games" (Goodwin and Nacht 1991, 44).

Still, teaching abroad probably has fewer professional tradeoffs than is commonly supposed. According to the Carnegie Council survey, it is
American professors who are isolated from the rest of the academic world. U.S. faculty welcome foreign scholars as visitors and colleagues and value the diversity that foreign students bring to their classrooms. Nevertheless, the survey found that American academics came in dead last in terms of reading foreign books, teaming up with foreign researchers, publishing in foreign journals, tracking intellectual trends abroad, and internationalizing curricula. Only half of U.S. professors felt that connections with foreign scholars were very important. Twothirds of American academics had not traveled overseas professionally in the past three years (Altbach and Mcgill 1998).

Of course, American academics are not indifferent to what happens in other countries. Rather, they are confident that the U.S. is the Mecca of higher education, and that it is also the Baghdad, the Cairo, and the Qum-that is, the hub of learning and scholarly exchange. After doing without a good research library and sitting jet-lagged through conferences in North America, I would hate to have to argue against this proposition. Still, internationalization brings an important leaven to the field. The comparative perspective that teaching abroad affords can spur insights into both American and foreign politics. Teaching abroad may lead to better-and better informed-pedagogy, to reflection on political culture (and the interplay of cultures), and to a keener sense of how ideas are conveyed and interpreted. Finally, an acquaintance with other intellectual traditions can make American political science a genuinely cosmopolitan profession.

\section{Notes}

* I wish to thank Elif Özerman and Bradford Dillman for their helpful comments on a draft of this essay. I am also indebted to Miriam Kazanjian of the Coalition for International Education and to Judy Pehrson of the Council for International Exchange of Scholars for their assistance.

1. The Carnegie Council study, the first of its kind, was carried out in 1991 and 1992. Surveyors queried academics in the United States, the United Kingdom, Germany, The Netherlands, Russia, Sweden, Hong Kong,
Japan, South Korea, Brazil, Chile, Mexico, Irael, and Australia. The number of respondents in each country ranged from 1,000 to 3,500. Common methods were used to ensure a random sample, although the survey is probably biased toward more settled faculty. See Boyer, Altbach, and Whitelaw (1994) for a fuller description.

2. Exact qualifications for most countries are set out in National Academic Recognition Information Centre (1996).
3. The Fulbright program operated as a Iargely autonomous branch of the State Department from the program's inception in 1946 until 1978 , when it was incorporated into the U.S. Information Agency. In a recent reshuffling of Washington's foreign affairs agencies, USIA was abolished altogether and educational exchanges were folded into the State Department, where they will be administered independently of the government's public relations functions.

\section{References}

Allaway, William H. 1991. "The Future of International Educational Exchange." American Behavioral Scientist 35(1): 55-63.

Altbach, Philip G. 1998. Comparative Higher Education: Knowledge, the University, and Development. Greenwich, CT: Ablex Publishing Corporation.

—, and Patti Mcgill. 1998. "Internationalize American Higher Education? Not Exactly." Change 30(July-August): 36-39.

Anderson, Gary. 1999. "Fifty Years of European Peace: The Role of International Education in German-American Relations." Vital Speeches of the Day 66(1): 18-24.

Blight, Denis. 1995. International Education: Australia's Potential Demand and Supply. Canberra: IDP Education Australia.

Bollag, Burton. 1999. "Private Colleges Reshape Higher Education in Eastern Europe and Former Soviet States." Chronicle of Higher Education, June 11, A43-44.

Boyer, Ernest L., Philip G. Altbach, and
Mary Jean Whitelaw. 1994. The Academic Profession: An International Perspective. Princeton, NJ: The Carnegie Foundation for the Advancement of Teaching.

Choukri, Muhammad. 1996. Streetwise. London: Saqi Books.

Daniel, John. 1996. "The World Cuisine of Borderless Knowledge." Times Higher Education Supplement, August 9, 10.

The Economist. 1997. "The Knowledge Factory: A Survey of Universities." October 4-10, Supp.

The Economist. 1998. "Subversive Values: American Schools Abroad." June 20, 5354.

Goodwin, Craufurd D., and Michael Nacht. 1991. Missing the Boat: The Failure to Internationalize American Higher Education. Cambridge: Cambridge University Press.

Graves, John E. 1979. "Building Conceptual Bridges to Shi'a Islam." Cable from U.S. Embassy, Tehran to U.S. International Communication Agency, August 19. Digi- tal National Security Archive item IR02911.

Halliday, Fred. 1999. "The Chimera of the "International University." International Affairs 75(1): 99-120.

Kameoka, Yu. 1996. "The Internationalisation of Higher Education." $O E C D O b-$ server, Issue 202(October-November): 3436

Knight, Jonathan. 1987. "A Question of Judg ment: The Rights of an American Scholar Abroad." Academe 73(1): 39-42.

Law, Wing-Wah. 1996. "Fortress State, Cultural Continuities and Economic Change: Higher Education in Mainland China and Taiwan." Comparative Education 32(3): 377-94.

Lewis, Lionel S., and Philip G. Altbach. 1995 "Professional Attitudes-An International Survey." Change 27(May-Junc): 50-57.

MacWilliams, Byron. 1999. "Diplomas for Sale on Moscow's Streets." Chronicle of Higher Education, July 16, A43-44. 
Mulcahy, Kevin V. 1999. "Cultural Diplomacy and the Exchange Programs: 1938-1978." Joumal of Arts Management, Law and Society 29(1): 7-28.

National Academic Recognition Information Centre. 1996. International Guide to Qualifications in Edacation. 4th ed. London: Mansell.

National Center for Education Statistics. 1997. Projections of Educational Statistics to 2007. NCES 97-382. Washington, DC: U.S. Government Printing Office.

Scott, Peter. 1998. "Massification, Interna- tionalization and Globalization." In The Globalization of Higher Education, ed. Peter Scott. Buckingham, England: Open University Press/The Society for Research into Higher Education.

Shestopal, Helen. 1999. "Observations on the

Transformation of the Political Science

Community in Post-Soviet Russia." PS:

Political Science and Politics 32 (December): 713-20.

Szyliowicz, Joseph S. 1994 "Education and

Political Development." In Politics in the

Third Turkish Republic, ed. Metin Heper and Ahmet Evin. Boulder: Westview Press.

Tysome, Tony. 1999. "Demand for Degrees Outstrips Supply." The Times Higher Edhcation Supplement, March 19, 8-9.

Welch, Anthony R. 1997. "The Peripatetic Professor: The Internationalisation of the Academic Profession." Higher Edacation 34(3): 323-45.

Yin, Jun. 1998. "Placement Report: Political Science Ph.D.s and ABDs on the Joh Market in 1997." PS: Political Scince' and Politics 31(December): 818-25.
The

Thatcher Years

\section{The Rebirth of Liberty?}

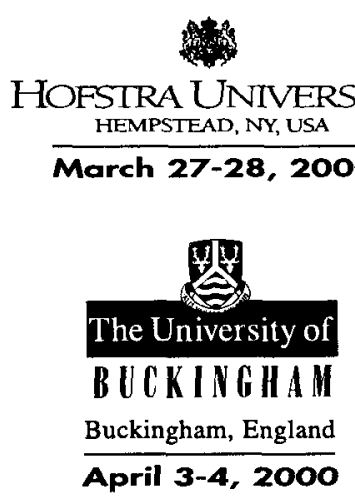

April 3-4, 2000

\section{An International Conference}

$\mathrm{H}$

ofstra University in the United States and the University of Buckingham in the United Kingdom are proud to sponsor an international conference on the life and influence of Lady Thatcher, Prime Minister of the United Kingdom from 1979 to 1990. Major figures from the Thatcher period, including Lady Thatcher, will participate.

Web site: wwwhofstra.edu/thatcher • Call: (516) 463-5669

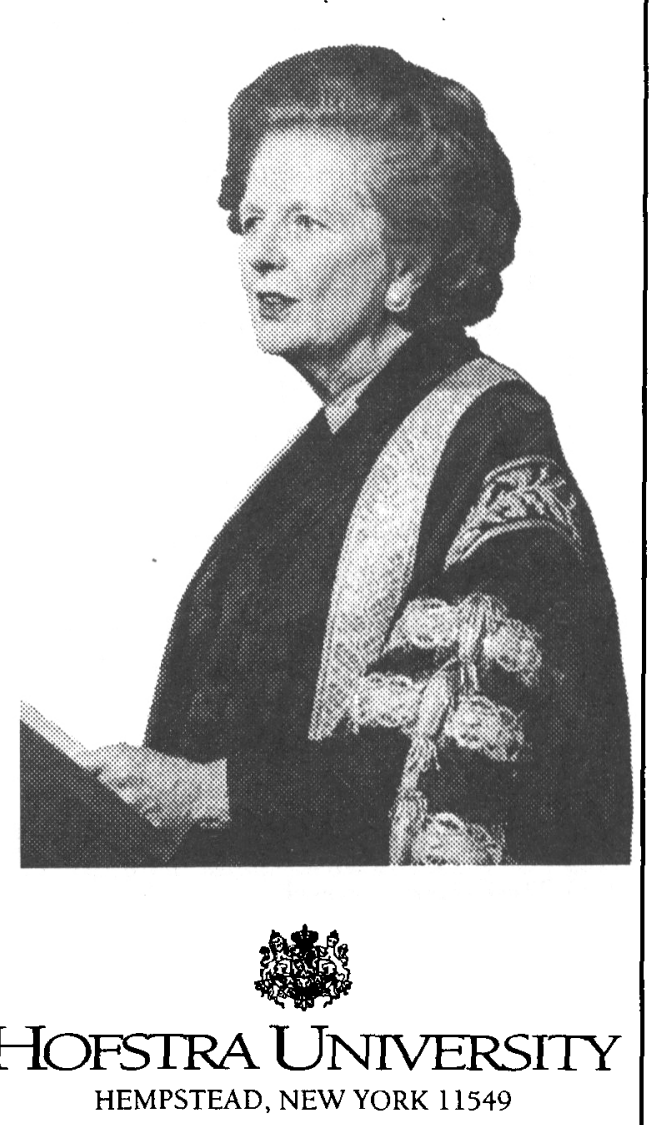

Major Conference Sponsor and Official Airline of the Margaret Thatcher International Conference 